\title{
FROM COMMUNICATION TO ART: MCDONALD'S AND FLAT DESIGN
}

\author{
Ludovic Chatenet \& Anne Beyaert-Geslin
}

\begin{abstract}
The status of communication objects or images always changes. This paper proposes to observe this phenomenon from a semiotics point of view in order to analyse how a brand reinvents its visuals and how this reinvention is related to a new marketing strategy. In fact, this paper tries to show how meaning of posters reveals the importance of brands in contemporary everyday life. We will show that the ads created by TBWA for McDonald's 2015 campaign are rather considered as an aestheticisation project than an artisticisation. While inspired by the brand's "mythologic" history and pushing properties of the product into the background, flat design exemplifies the latest forms of life to date. Therefore, brands seem more involved and rooted in social life as their communication strategy is rather based on gathering a community than advertising their products. Visual ads are hence absorbed by an aestheticisation practice, specific to connected life, from which they adopt the norms. As it remains distinctive, art also maintains its criticizing position and Murakami's superflat thus discloses a certain disenchantment concealed in standardised designs.
\end{abstract}

\section{Keywords}

Advertising; brand; design; hypermodernity; mythology; semiotics

\begin{abstract}
Resumo
O estado dos objetos ou imagens de comunicação está sempre a mudar. Este artigo propõe-se observar este fenómeno de um ponto de vista da semiótica, a fim de analisar de que forma uma marca reinventa a sua imagem e de que forma esta reinvenção está relacionada com uma nova estratégia de marketing. De facto, este artigo tenta demonstrar de que forma o significado dos pósteres revela a importância das marcas na vida quotidiana contemporânea. Iremos demonstrar que os anúncios criados pela TBWA para a campanha de 2015 da McDonald's são mais considerados um projeto de estetização do que uma artistização. Apesar de inspirado na história "mitológica" da marca e empurrando as propriedades do produto para segundo plano, o flat design exemplifica as últimas formas de vida até à data. Por conseguinte, as marcas parecem estar mais envolvidas e enraizadas na vida social, uma vez que a sua estratégia de comunicação se baseia mais em reunir uma comunidade do que em publicitar os seus produtos. Os anúncios visuais são, consequentemente, absorvidos por uma prática de estetização, específica de um estilo de vida conectado, do qual adotam as normas. Como continua a ser distintiva, a arte também mantém a sua posição de crítica, e o superflat de Murakami revela, assim, um certo desencanto que se esconde por trás de designs normalizados.
\end{abstract}

\section{Palavras-chave}

Design; hipermodernidade; marca; mitologia; publicidade; semiótica 


\section{INTRODUCTION}

If we imagine Barthes writing his Mythologies today, the McDonald's hamburger would probably be mentioned because, as a language unit, its "meaning is already complete, (and) suggests a knowledge, a past, a memory, an order allowing to compare facts, ideas, decisions" (Barthes, 1957, p. 190). Not only does this hamburger produce "a rich, experienced, spontaneous, innocent, unquestionable image "embedding" a whole system of values: a story, a geography, a moral, a zoology, a literature" (Barthes, 1957, p. 190), but also its meaning remains open and available for other investments. More than just a witness of culture sedimentation, this McDonald's myth offers as well a manifestation plane to its discourse. In fact, no product can handle alone its commercial career and needs to be empowered by additional identity imparted by the brand. In this case, it becomes a myth as it conveys the American dream and becomes an emblematic figure of cultural globalization. That way, McDonald's hamburger tells the story of a brand's journey across the world, but at the same time the story of consumption, as a concept, from industrialization era to modernity (Semprini, 1995a, 1995b) and now to hypermodernity. Lately, many authors have pointed out how brands gradually took position at the centre of social life and now contribute to a hypermodern hedonistic form of living (Ceriani, 2015) as they weave affective bonds with consumers henceforth defined as communities of fans. Thus, the brand became a full-time actor of social life, spreading its influence more easily as it loosens its ties with the product and relegates its properties into the discourse background.

This paper analyses ads from 2015 McDonald's campaign created by the TBWA agency in Paris. These ads are drawings representing the famous hamburger and a couple of other flagship products. They are depicted using flat tint colouring (flat design), like in colouring books, and circulated through miscellaneous media (posters, phone shells...); moreover they are sometimes displayed in two parts creating a narrative micro-sequence. The distinctive feature of this commercial message is to be significantly simplified. That is, it renounces image/text syncretism and it schematizes and stylizes the images of the products reducing them to appear as a juxtaposition of dots over a white background. Through this minimalist choice, sometimes compensated by the maximalist format of the medium ${ }^{1}$, McDonald's both renounces "plugging" 2 effect and the rhetoric of praise and persuasion that defines advertising in general (Adam \& Bonhomme, 1997). Rather than establishing the persuasive force of marketing, McDonald's chooses to set back and uses benefits from brand's notoriety to encourage the audience into taking the initiative and consult this "mythologic capital", that is, the thickness of sedimented discourse. This minimalist graphics capitalizing over a "maximalized" past condenses (Fontanille, 2015, p. 14) a contemporary form of life: hypermodernity. As they seem to deny any commercial purpose, these irenic images cannot be considered art or an artisticisation, but rather a hypermodern aestheticisation.

\footnotetext{
'We are thinking here of the double poster implemented in the main hall at Bordeaux Saint-Jean train station.

2 In the essays entitled "L'Identité selon Waterman" and "La voie des logos", Jean-Marie Floch exemplifies the repetitive rhetoric of advertising headlines. For further information, please see Jean-Marie Floch's, Identités visuelles, Presses universitaires de France, 1995.
} 


\section{MODERN AND HYPERMODERN ADVERTISING}

Various authors studied the history of the concept of brand from its older origins back in antiquity and its more recent roots in the second half of $19^{\text {th }}$ century. According to them, brand rose after the 1920 s following different stages, from modernity to today's hypermodernity. This trajectory can be defined as diachronic temporality which folds the present on the past and delivers him to memory and language. This first acceptation of temporality can be compared with to the one we determined while analysing everyday objects (Beyaert-Geslin, 2015). From Locke's proposition (1998[1689])3 , suggesting that we need signs to communicate and share our experiences, we put forward the idea to consider objects not for what they are but as manifestation planes of the time they allow to grasp and share. Otherwise, objects would be the matter of time. The first time string that offers object to memory and language must be linked with a second one, a historical temporality that, on the contrary, locates objects in the present of experience, and a third one, depicting time of action. We named them diachronic time, historic time and time of the doing.

This theoretical framework can be used for our analysis. Next to the first temporal frame that recalls the history of McDonald's, we would notice a historic temporality, which, linking past and present, connects the expressive desaturation of these posters to the saturation of former posters. This acceptation of temporality considers that discourses come one after another and builds a rhetoric based on previous materials. In fact, this second acceptation of time argues that advertising rhetoric is based on memory.

In this respect, semiotics analysis applied to advertising emphasized and illustrated its special relation with memory. For instance, Floch (1995) reveals a rhetoric of repetition and alliteration ("there is some Urgo in the air; there is air in Urgo"), as well as a generative principle joining with the semantic bricolage that allows the gradual construction of meaning from a previous bedlock of memorized language units ${ }^{4}$. If this principle of gradual construction leads to discursive expansion, in our case, temporality rather supports rhetoric of diminution or condensation. Thus, the "less" contrasts with the "more", the latter being the canonical emphasis of advertising rhetoric. This type of emphasis supports the fact that everything has already been said about our famous hamburger, and even more, everything has been shown and valorised by photographs that illustrated its volume, the crispy freshness of salad and every single gustatory property through careful staging and tasty synaesthesic conversions.

As it uses desaturation, the drawing reminds the photographic inheritance humankind keeps in its memory. The work of Sontag (2000, p. 15) can enlight this particular point. Indeed, while she describes photography as a mean to seize the world, the sociologist mentions a catalogue of images already available; she sustains that "the whole world fits in our mind as an anthology of images". Since the invention of photography, it

\footnotetext{
3 "And because the scene of ideas that makes one man's thoughts cannot be laid open to the immediate view of another, nor laid up anywhere but in the memory, a no very sure repository: therefore to communicate our thoughts to one another, as well as record them for our own use, signs of our ideas are also necessary".

${ }^{4}$ Consult Floch's introduction named “du design au bricolage” in Jean-Marie Floch's Identités visuelles (1995).
} 
is certain that there is "not a single thing (of the world) that has not been photographed". Following the conception of Benjamin (1931/2012) who rather considers photography as a "marketing" tool than a mean for knowledge; we could understand this abandonment of photography as the omen for a more general renouncement to expressiveness that would rely on the state of saturation of our mind. Indeed, everything works as if the drawing, via its expressive lightness, introduces a rupture within the semantic saturation of the advertisement, and as if graphic design stands as a possibility of innovation and differentiation in a world where the photographic "overflow" tends to reduce contrasts, hence preventing the distinctive action of identity ${ }^{5}$. Moreover, we can think that subdued contrasts between photos are here replaced by the enhanced contrast conveyed by the relation between drawings and photos: an "inter-media" contrast, that is, between two different materials carrying images, seems to subsume "intra-media" contrasts, that is, within the same type of material. If the era of expressive desaturation comes after the era of saturation, then flat design with its simple forms and flat tint also appears as a new way for keeping volumes in memory through "compacting". The forms that use to embody the presence of objects through an actual mode of existence now potentiate this presence.

A third conception of temporality can be found in the time of observation of the poster and defined as the present of experience. Basically, images are active because they put the body in motion and, recalling the expression of Greimas (1983, p. 73), they "make us do". This thesis is also supported by Fontanille's (2002) concerning pictograms. He points out that even before describing or representing reality, they have a hold over it and they can both transform us or our world. Pictograms draw elementary scenes organized around an action and allow identification. For instance, the pictogram for a "garbage bin" makes sense because it is completed by a character representing the movement of throwing. Each time, the interpretation of a pictogram implies the mediation of an act, that is, from a semiotics point of view, a predication. If pictograms can be described as active images, we can definitely say the same about artistic images, which also put the body in motion. First of all, the motion is determined by changing the scale of the image. Likewise, we noticed (Beyaert-Geslin, 2015b) that large paintings illustrate this "causing-to-do" or factitivity (Beyaert-Geslin 2017) by pushing away observers' body to a far distance in order to allow the whole picture to conform to their field of vision and later attracting him closer to examine the details. Thus, the translations far/close, here amplified by scale contrasts, respectively allow either a figurative or a plastic reading of the picture.

How does the McDonald's ad convey action? What does it "make do" and how? Often presented alone, the hamburger poster is sometimes associated with a second poster, made of bigger dots, and focused on a particular detail. If chromatic continuity permits to link together these two posters positioned side by side, it also stimulates the observers so that they can relocate the detached part within the whole. In this respect,

5 Visual identity can be either approached as conformity or difference. This distinctive identity is revealed in the analysis of Apple's logo described as an opposite system to IBM's. Refer to Floch. 
the ad draws attention like a puzzle that would also suppose positioning a small piece into a totality represented by the model. The association of the cut-shape, the form and the colours, which make up the expression plane of the piece (blue coding for the sky, green for the landscape...), bring up the hypothesis of localization. The observer proceeds the same way while watching McDonald's ad, which, thanks to the conjunction of many contrasts for the details, can easily depict the burger as a whole.

Even if this game can be regarded as an action of the mind or a conceptual game, it does not exclude another movement represented by the pair of posters defining it as a narrative micro-scene. Indeed, the difference between the hamburger pictured as a whole and its details does not lie only within the oscillation between two strategies of observation (Fontanille, 1999): on one hand, an encompassing strategy allowing to contain the product in the frame of the gaze, that way, it gets all the attention; on the other hand, an elective or particularizing strategy, focused on the specimen or specific "part". But this does not mean unveiling two opposite points of view on the product. As the observer deduces the small dots became bigger, he creates the continuity that confirms eidetic and chromatic isotopies. Thus, he can reconstitute the two stages of narration that brings him cognitively closer to the hamburger. More precisely, the advance of the gaze symbolizes the advance of the body, the hand then the mouth and permits to recreate the scene of savouring. This is the third temporality staged by the ad.

This move toward the hamburger can be described as a swinging between two framings. A centred and steady point of view takes the figure away from the edge revealing the white background. This effect follows the principle of vignetting (Groupe $\mu, 1992$, p. 304). That is, it puts the background in the back potentiating it while the indented and detached figure is brought forward and actualized with force. This construction makes the identification of the hamburger easier thanks to optimizing the figural operation of constituting a background/figure relation. The different parts of the product are distinguished thanks to contrastive colours (beige for bread, green for salad, yellow for cheese...), following Tufte's recommendations (1997, pp. 176-177) about cartographic territories, which means that they insure both a distinctive function and facilitate the understanding of the structure. The combination of properties, such as simple shapes emphasized by the background and contrastive colours, enable representation to create a perceptive "obviousness", a belief-in-being, that is, an epistemic regime that comes under construction and fabrication (Jeanneret, 2001) while pretending banality. Advertising uses this strategy of optimizing the visible to unwind this temporal dimension integrated into Bertin's definition of a graphic image described as a "perceptible significant form in the shorter instant of vision, spontaneously perceptible" (Bertin, 2007, p. 146).

The graphic hamburger is a prototype, as in, a significant occurrence sparing the need to consult the others. In this respect, he recalls the opposition type/token developed by Eco (1975). All the specificities of tokens have been gathered, converted and schematized by this type-hamburger. We describe here a specific purpose of the drawing that distances itself from particularisms and contingency of photography (Barthes, 1980) and discharges from the present of particular tokens to escape time. 
Finally, all these observations confirm that the McDonald's ad is an example of flat design. Indeed, the analysis underlined its minimalism used to strip the visual off any unnecessary information. This kind of image clearly operates a shift from an experiencebased format, which would represent the embodiment of a real object (e.g. Skeuomorphism), to a format optimized for sharing information. The acclimatization to new consumption practice tied to the rise of connected existence requires another conception of aesthetics made of flat tint and vector graphics reproducible and reusable intra and inter-media. Through their extreme simplicity these objects become timeless because they do not seem to bear any historically relevant technique. They can only be located in the time of exchange and information, and draw forth references from the sphere of usage. This temporality is particularly important because it allows an extraction of the image from the time of experience and, at the same time, a recollection of the brand's history (time of doing).

As they try to insure a better recognition of every object, flattening out any singularity, McDonald's product images act like our childhood picture books. However, unlike these picture books, they are not associated with any verbal utterance. They neither mention the name of the product nor the name of the brand. In fact, on the contrary, they are both solicited through images, thus, they ask for a pairing with text. A real clue leads us to identifying the name of the brand, symbolized by a circled $M$.

Posters sometimes work in twos. The point of view on details is based on diagonal lines that produce a decentring. It generates a sort of instability, by putting the figure in motion and reintroducing it into the temporality of the body. Besides, the distance oscillation requires eidetic conversion that opposes two figurative models. For that matter, every step closer opens up another world. The famous comment of Pascal supports our point ("a city... from afar is a city...; but as we get closer, it is houses, trees, tiles, leaves, grass... to the infinite"). In our case, the close up on the hamburger does not only reveal another possible world but also connects two figurative models that appear to be reversible. The hamburger is depicted as ranks of thumbs-up; the pack of fries as smileys; the chocolate cream as music notes. Identifying these encompassing and encompassed forms lead the observer to a two-way trip into the narrative scene by forcing him to "enter" the image of the whole before the smaller units bring back to it in order to identify precisely these smaller units. This closing in, thus, reveals another figurativity, recalling John Maeda's compositions that compare a figurative micro-model (the cap of a pen, for instance) with a figurative macro-model (a sunflower, fireworks...). In this case, the visual appears to be a composite form describing a totality (a burger, ice-cream, happy meal box) acting as the total of small units (thumbs, notes, hearts). Then, we can find a cohesive dimension keen in defining this whole-part relation as an organic link between two levels of meaning that associate the form of an iconic product of the brand to "emotional" individual entities. 


\section{SYNAESTHESICS CONVERSIONS}

This shift between two expression planes and two scales of form (Beyaert-Geslin, $2015 b$ ) is also a synaesthesic shift that diversifies the properties offered to perception. An image can mobilize many perceptive modalities but they all necessarily converge through sight. In the case of food and the reconstitution of savouring scenes, McDonald's ad has to consider non-visual properties, olfactory, tactile and gustatory, and convert them into visual data. This is what packaging basically does. Thus, McDonald's narrative sequence allows chocolate to play music (chocolate ice-cream is made of music notes); moreover, the diagonal and spiral motif replicates the pattern of spreading odour or sound.

In this respect, condensation does not ignore semantic and sensible diversification. Although the ad looks simplified, it varies and unfolds the imaginary of forms while contributing to the re-enchantment of the world. As micro-units used here are basically language units that are already meaningful, it confirms the principle of semantic bricolage. They recall a large range of universes of value including emotes and emoji from youth culture, numeric pixels that, as we pointed out before, have already inspired the great figure of contemporary numeric art: John Maeda (Beyaert-Geslin, 2003), or the graphic dots that similarly inspired Pop art artists who were representative of 1960 s American culture and still spread in todays' consumer goods designs. Beyond a simple mentioning, these references could moreover work as metalinguistic comments through which images would state their origin reminding that the generative dot is the very beginning of all images (Beyaert-Geslin, 2009).

Thus, in spite of their apparent simplicity, graphic images possess all the components of a form of life. Indeed, they manifest expressive recurrences that can, on the expression plane, refer back to axiologies. Simple forms, mainly curved and defined by their contrastive colours in flat tint, recall different cultural references such as current art styles, electronic messages and a specific type of contemporary social interaction based on community togetherness. If on the one side bright colours can be associated with positive meanings, on the other side, smileys' smiles and music notes' waving patterns underlining the connotation of pleasure, already related with the dessert, confirm this system of value. Consequently, signs refer to a "rhythmic style" or a "modal and axiological attitude" which, according to Fontanille (2009), defines a form of life. Forms of life are languages (Fontanille, 2015, p. 14) that translate behaviours related with expressions through interpretation. In our case, we could underline that design or art offers a means of expression to universes of life shared by a community of users. Indeed, different universes of meaning intertwined in the ad take shape via recurring expressive traits (colours, curves) conveying similarly recurring contents (youth, pleasure, contemporaneity, community, creativity) so that they are sufficient to build a consistent form of life. In any case, the recurrence of expressive traits is compatible with the diversity lying within the whole-parts relationship (the hamburger-the thumbs-up...) that describes forms of life as the addition of individual "opinions", users, fans who subscribe to it. Thus the advertising discourse changes its orientation because McDonald's does not relay the image of particular goods (an actual picture of a "fresh" burger) but uses, via the design, codes 
shared by a certain community. The codes shared by the target audience encompass modern connected communication (social media emotes) but has to remain quite general to ensure broader recognition. As a consequence, the plastic dimension no longer defines the brand and its promise as taste only but also as a practice recognized and shared by users. Then, we can adopt a critical approach of meaning based on the forms of life that convert social choices into identity sources.

Our observations, solely based on one brand, can lead to other discussions about the creation of a new communication space that would characterize a specific form of interaction found in modern societies. Within this framework, brands communication reveals the issue of the social space of users gathered around a promise, which is not only the benefits of a product but rather the lifestyle the brands is borrowing the values from.

\section{ArTiSTICISATION OR AESTHETICISATION ?}

So far, we have observed how McDonald's puts its notoriety to the test of a kind of un-familiarization discourse (or familiarity checking discourse) that carries on with traditional values associating them at the same time with creativity values, togetherness and youthfulness as a contemporary form of life. This approach raises a couple of questions. First, what object is depicted? Does the hamburger still represent its model of bread and meat, its derived images, or McDonald's myth? The drawing of the prototype tells a cultural and media-related ode to posterity as it "compresses" a whole universe of values. Through this semantic extra, its story eventually convenes with consumer goods such as Brillo boxes or Campbell's soup made by Andy Warhol into artistic motifs. As it modifies the destiny of products, the drawing confirms McDonald's mythology. But are these decorative images that seem to deny any commercial purpose artistic? What would be the condition for such a qualification? From our point view, artisticisation is determined by the change of place, the easier way would be to transfer pictures to a museum or a gallery. Another condition, closely related with the first, is the choice of the artist. According to the definition from the Dictionnaire du surréalisme, it is the case of the ready-made, an ordinary object promoted to the dignity of a work of art thanks to the decision of the artist. Duchamp offered the most powerful illustrations of this genre. Whether it is the place or the artist's choice, we can generally say that the status of an image or object is decided by implementation, that is, the way it is used within culture (Goodman, 2006). But these posters appear on billboards, packaging and station hall walls; as a consequence, they are commercial images. Despite this fact, we could still take them home to decorate a room or a notebook like we do with what we call "by-products". Insofar as the form of life turns the consumer into a public or a fan community, image status could change all the same. If it's not an artistic status, we can nonetheless give them an aesthetic status. These images involved in social life contribute to the general aestheticisation of the world described by the authors of hypermodernity (Lipovetsky \& Serroy, 1993). They navigate gracefully between and betwixt two contemporary practices as small peaceful forms that seem to renounce their commercial purpose. 
Hypermodernity is defined by Lipovetsky as a new modernity or a hyperbolic modernization. It connects a space where individuals and communities redefine their view on humans, on their environment and their social practices for personal fulfilment. Generally, hypermodernity is rooted in both a conception of art that obeys global markets as well as hyper-consumption phenomena and hedonism that spread at high speed across digital space. In this space, which is dominated by information and where individuals invest themselves via subscription and un-subscription, following consumers' behaviours, media impose their communication models that vehicle recognizable forms of life. That is, consumer behaviour. The living space, thus saturated by incomplete and short-lived semiotic forms, requires a critical point of view concerning not only mediation forms (Fontanille, 2015, pp. 137-159) but also design and art status.

The superflat spread by the plastic artist Takashi Murakami seems to follow this trajectory. Thus, we can wonder: how is superflat related with the hypermodern form of life? Moreover, as this movement claims to be art, how can he allow criticism of hypermodernity? Superflat is by definition a movement closely related with the digital world (flat TV and computer screens) and with the art of Japanese animation movies. It is inspired by Japanese tradition (head-on drawings) and UK's pop culture but also by new digital technologies. Consequently, it goes way beyond art, in a traditional sense, as it involves multi-disciplinary skills from scriptwriters, comic book artists, mode sketchers and graphic designers. Superflat is not only an artistic movement but first of all a critical point of view on the mass consumption society that developed in Japan in the 1990s and 2000s. Although it clearly refers to the otaku universe of video games and multimedia lovers, it also personifies a disillusioned position regarding a world losing its values. Indeed, even while depicting a childish world and the lightness of adult life, Murakami gives to his characters (e.g. Dob) a wicked touch embodying perfectly a period within which the pink tint (kawaii) also bears a feeling of deviance.

According to Lucken (2001, p. 240) a certain militancy can be noted in Murakami's superflat as it consists of "mixing without creating differences, refusing hierarchies, balancing values; seeing the world as a series of intertwined planes". In this space without perspective, Murakami combines art and product in order to question the forms of cultural identity. As it reveals its tensions and contradictions, superflat reassesses flat design's irenism. He returns social asperity to a phenomenon which aim was precisely to reduce it.

In the case we studied, we can consider that McDonald's no longer sells a product, the hamburger, but the subscription to a particular behaviour, or lifestyle. Lifestyle is beyond food consumption as it involves social value implying the possibility to develop communication over a territory of values condensed in many forms that convey them. That is why, for instance, joyful notes, smileys and thumbs up transform the product hamburger within the graphic space. The hypermodern form used (flat design) strips the visual of its artistic meaning and puts it at stake between aesthetics and design or even, according to Fontanille, between ethics and strategy. Maybe the hypermodern form of life plays with the confusion between them to conceive ambiguous consumption models and life projects because, as now, ethos seems to have become marketable. 
Art has always been a vector for new ideas and innovation (Lotman, 1999) but it is also the first critical field to reveal new possible meanings. Thus, artistic enunciation opposes collective praxis that tends to constrain and regulate meaning. Consequently, the effect of aestheticisation rises potentially as an intermediary that resists an artistic implementation considered too close to an individual praxis (beau geste) and prefers the game of collective practices, internal references and life designs. It is a way for collectivizing art.

\section{Conclusion}

This paper aimed at analysing how brand design strategy could redefine the status of communication images. Beyond this redefinition, we managed to confirm that brands are located at the centre of social life and tend to position their images accordingly. Thus, their advertisements convey forms of life, consumer's behaviours, rather than their product like before. Brands have become a full-time actor of social life spreading their influence more easily as there is now less relation with a product than with a lifestyle.

The analysis of McDonald's 2015 advertising campaign (TBWA) allowed us to point out a change in images and even a new advertising rhetoric. The visuals we studied are based on flat design that simplifies forms and volumes. Through this type of design, McDonald's communicates its myth via a hamburger-type removed from experience and now reinterpreted by design which rebuilds its shape with a group of small emotes. The fact that the brand abandons "realistic" or experiential pictures of burgers shows that it adapts to a new practice of consumption and communication.

Indeed, McDonald's uses flat design to condensate its values and associate them with those of creativity, togetherness and youthfulness that characterize a contemporary form of life. Thus, advertising discourse conveys a perceptive universe that stimulates imagination through a stereotypical aesthetic treatment. These remarks suggest that todays' societies, defined as hypermodern, no longer trade objects but forms of life, subscription values to users communities.

Finally, flat design raises the issue of this hypermodern form of life as it becomes a way of communication, optimized for connected consumption. Products reinterpreted by design disappear in favour of references that locate the brand at the centre of a social network bearing its values. Since brands promise membership to a community recognizable by its choices, using flat design creates an aestheticised space aiming at enchanting visuals condensing the imaginary of a specific world. But Murakami's point of view allows criticism of these aesthetics of consumption that otherwise would only be an artificial peaceful surface particular to marketing. Indeed, the superflat movement led by Murakami shows the existence of an underlying disenchanted reality that goes beyond the equalization of values and their visual embodiment. In short, brands try to gather consumers flattening values but hypermodernity is far more complex. It cannot erase user's complexity as their identity is in tension between multiple senses of belonging. Flat design is not only the solution to address the conflict of individual identities but it is, on the contrary, their possibility of eruption. 


\section{BIBLIOGRAPHIC REFERENCES}

Adam, J-M. \& Bonhomme, M. (1997). L'argumentation publicitaire, rhétorique de l'éloge et de la persuasion. Paris: Nathan.

Barthes, R. (1957). Mythologies. Paris: Livre de Poche.

Benjamin, W. (1931/2012). Petite histoire de la photographie. Paris: Allia.

Bertin, J. (1967/1998). Sémiologie graphique: Les diagrammes, les réseaux, les cartes. Paris: Les réimpressions de l'Ecole des Hautes Études en Sciences Sociales.

Beyaert-Geslin, A. (2003). L'esthétique du pixel. L'accentuation de la texture dans l'œuvre graphique de John Maeda. Communication Q Langages, 138, 23-37. Retrieved from http://www.persee.fr/web/revues/home/ prescript/article/colan_0336-1500_2003_num_138_1_3233

Beyaert-Geslin, A. (2009). Faire un point. In A. Beyaert, M. G. Dondero, \& J. Fontanille (Eds.), Actes du Colloque de Limoges, Arts du Faire: production et expertise, Nouveaux actes sémiotiques. Retrieved from http://epublications.unilim.fr/revues/as/3232

Beyaert-Geslin, A. (2015a). Sémiotique de l'objet. La matière du temps. Liège: Presses universitaires.

Beyaert-Geslin, A. (2015b). La réforme du format. Quelques leçons pour embarquer sur un radeau. In T. Migliore, (Ed.), Micromaco, scale jumping in art. Bologne: Arachne.

Beyaert-Geslin A. (2017). Factivitité. La postérité d'un concept. Semiotica, Journal of the International Association for Semiotics Studies, 214, 393-407.

Ceriani, G. (2015). Sémiotique et marché. Les dynamiques, les problèmes, la nécessité. Actes Sémiotiques, 118. Retrieved from http://epublications.unilim.fr/revues/as/5374

Eco, U. (1976 [1975]). La production des signes. Paris: Le Livre de Poche.

Floch, J-M. (1990). Sémiotique, marketing et communication. Sous les signes, les strategies. Paris: PUF.

Floch, J-M. (1995). Identités visuelles. Paris: PUF.

Fontanille, J. (1999). Sémiotique et littérature. Paris: PUF.

Fontanille, J. (2002). Le langage des signes et des images. In Y. Michaud (Ed.), Université de tous les savoirs. Qu'est-ce que l'humain? Volume 2. Paris: Odile Jacob.

Fontanille, J. (2008). Pratiques sémiotiques. Paris: PUF.

Fontanille, J. (2015). Formes de vie. Liège: Presses universitaires de Liège.

Goodman, N. (2006). Manières de faire des mondes. Paris: Folio.

Greimas, A. J. (1983). Du sens II. Essais sémiotiques. Paris: Seuil.

Lipovetsky, G. \& Serroy, J. (1993). L'esthétisation du monde. Vivre à l'âge du capitalisme artiste. Paris: Gallimard.

Locke, J. (1689/1998). An essay concerning human understanding. Oxford: Clarendon Press.

Lotman, I. (1999). La sémiosphère. Limoges: Pulim.

Lucken, M. (2001). L'art du Japon au vingtième siècle. Paris: Hermann. 
Jeanneret, Y. (2001). Les politiques de l'invisible, Du mythe de l'intégration à la fabrique de l'évidence.

Document Numérique, 1(5), 155-180.

Semprini, A. (1995a). Le marketing de la marque: approche sémiotique. Paris: Editions liaisons.

Semprini, A. (1995b). La marque. Paris: PUF.

Sontag, S. (2008). Sur la photographie. Paris: Editions Bourgois.

Tufte, E. R. (1997). Visual explanations, Images and quantities, evidence and narrative. Cheshire, Connecticut: Graphics press.

\section{BIOGRAPHICAL NOTES}

Ludovic Chatenet is a PhD in semiotics. His approach combines semiotics of culture and visual semiotics as methodologies for ethnological and anthropological analysis of identity and cross-cultural interaction. He uses images as models to study culture dynamics, that is, cultural representations and their evolution. During his thesis, he worked more specifically on imaginary and symbolism within Japan visual culture.

E-mail: ludovic_chatenet@mac.com

CeReS, University of Limoges, 39 rue Camille Guérin

87000 Limoges France

Anne Beyaert-Geslin is professor of semiotics and communication at BordeauxMontaigne University and director of the MICA (Mediations, Information, Communication, Arts) research team. She has edited sixteen collective books and review issues (in 2017 with Maria Giulia Dondero and Audrey Moutat, Les plis de l'image. Reflexivité et énonciation dans l'image, Lambert Lucas) and 4 books : L'image préoccupée, Hermès-Lavoisier, 2009 ; Sémiotique du design, Presses Universitaires de France, 2012 (italian translation in 2017 : Semiotica del design, Rimini, ETS Edition); Sémiotique des objets, la matière du temps, Presses Universitaires de Liège, collection Sigilla, 2015. Méthodes du portrait is to be published by De Boeck in 2017.

She has also written about 120 articles in semiotics of image, media and design in french, italian, spanish, english, chinese, portuguese and persan.

E-mail: anne.geslin-beyaert@u-bordeaux-montaigne.fr

Bordeaux-Montaigne University. Domaine Universitaire, 19 esplanade des Antilles, 33607 Pessac, France

\section{* Submited: 15-10-2016}

* Accepted: 22-01-2017 